Original Article

Received/Accepted Dates

15.10.2021/15.11.2021

DOI $\quad 10.52096 /$ jsrbs.6.1.7.13.34
Journal of Social Research and Behavioral Sciences

Sosyal Araştırmalar ve Davranış Bilimleri Dergisi

ISSN:2149-178X

Volume: 7 Issue: 13 Year: 2021

\title{
The Relationship of Psychological Resilience and Jealousy in Adults
}

Assist. Prof. Haydeh Faraji

Istanbul Aydın University

Faculty of Literature and Sciences

Department of Psychology

haydehfaraji@aydin.edu.tr

ORCID: 0000-0001-5306-6546

\section{Master Student Nilgün Berfu Boran}

Istanbul Aydın University

Graduate Institut

Department of Psychology

nilgunboran@stu.aydin.edu.tr

ORCID: 0000-0001-7891-8362

\begin{abstract}
Psychological resilience is defined as an individual's ability to positively adjust and adapt to adversity, difficulty, misfortune, or potentially traumatic event to maintain mental health. Psychological resilience is an innate personality trait and a process of positive adaptation when becoming face to face with adversity which can emerge at different life stages depending on the situation. Jealousy is a powerful emotion defined as a negative feeling that arises when an difficulty which includes perceiving a threat from someone else to a valued relationship. This complex emotion, which contains the feelings of anxiety and fear in his heart, is felt as a result of a damage or loss that may occur due to the physical or fantasy existence of a third person
\end{abstract}


who is seen as a rival in bilateral relations. Feelings of anxiety and fear, which are among the most basic contents of jealousy, are clear signs that the individual does not adapt to the situation they face. In this respect, the main hypothesis of our study is that there is an inverse relationship between resilience and jealousy in young adulthood. The research of the study, which was conducted online in 2021, consists of 188 female (75.2\%), 62 are male (24.8\%), in total 250 volunteers who's age are between 18-45 (mean age of the sample is 29) who lives in Istanbul. The findings of our study showed that there is an inverse relationship between resilience and jealousy.

Keywords: adulthood, pscyhological resilience, jealousy

\section{Yetişkinlerde Psikolojik Dayanıklılık ve Kıskançlık İlişkisi}

\section{Özet}

Psikolojik dayanıklılık, bireyin zihinsel sağlı̆̆ını korumak için olumsuzluklara, zorluklara, talihsizliklere veya potansiyel olarak travmatik olaylara olumlu şekilde uyum sağlama ve uyum sağlama yeteneği olarak tanımlanır. Psikolojik dayanıklılık doğuştan gelen bir kişilik özelliğidir ve duruma bağlı olarak farklı yaşam evrelerinde ortaya çıkabilecek zorluklarla karşı karşıya kalındığında olumlu bir uyum sürecidir. Kıskançlık, başka birinden değerli bir ilişkiye yönelik bir tehdidi algılamayı içeren bir zorluk ortaya çıktığında ortaya çıkan olumsuz bir duygu olarak tanımlanan güçlü bir duygudur. Kalbinde kaygı ve korku duygularını barındıran bu karmaşık duygu, ikili ilişkilerde rakip olarak görülen üçüncü bir kişinin fiziksel ya da hayali varlığı nedeniyle meydana gelebilecek bir hasar ya da kayıp sonucunda hissedilir. Kıskançlığın en temel içerikleri arasında yer alan kaygı ve korku duyguları, bireyin karşılaştığı duruma uyum sağlamadığının açık işaretleridir. Bu doğrultuda çalışmamızın temel hipotezi, psikolojik dayanıklılık ile kıskançlık arasında ters bir ilişki olduğudur. $\mathrm{Bu}$ doğrultuda çalışmamızın temel hipotezi, yetişkinlik öneminde psikolojik dayanıklılık ile kıskançlık arasında ters bir ilişki olduğudur. 2021 yılında online olarak gerçekleştirilen araştırmanın örneklemini İstanbul'da yaşayan 18-45 yaşları arasında 188 kadın $(\% 75,2), 62$ erkek $(\% 24,8)$ olmak üzere toplam 250 gönüllü oluşturmaktadır.

Anahtar Kelimeler: yetişkinlik dönemi, psikolojik dayanıklılık, kıskançlık.

\section{Introduction}

\subsection{Psychological Resilience}

Psychological resilience is defined as an individual's ability to positively adjust and adapt to adversity, difficulty, misfortune, or potentially traumatic event to maintain mental health 
(Ristevska-Dimitrovska et al., 2015). It is an innate personality trait (Taku, 2014 ) and a process of positive adaptation when becoming face to face with adversity which can emerge at different life stages depending on the situation (Herrman et al., 2011). Psychological resilience is a key factor for harmful stress and psychological health (Howell et al., 2017).

In explaining psychological resilience although many factors that play a role three general categories can be mentioned (Haase, 2004). These categories are; family harmony and support, personal structural characteristics and external support systems (social environment, colleagues, etc.). This point of view Fribog et al. (2005) "Self perception", "future perception", "structural style", "social competence", "family harmony" and "social resources" suggests a six-factor structure. Self-perception is about one's awareness of himself and basically who he is. express thoughts. Future perception point to one's future perspective However, the positive perspective plays an important role in the resilience process. Structural style of the person in a way selfconfidence, strengths, and self-discipline. Social competence While it is a factor related to whether people receive social support or not; family harmony shows. In this context, family adaptation and social support play an important role in the resilience process. Social resources show the social relationships that a person has.

\subsection{Jealousy}

Jealousy is a powerful emotion defined as a negative feeling that arises when an individual perceives a threat from someone else to a valued relationship (Salovey \& Rodin, 1988). It has emotional, cognitive, and behavioral dimensions. It is seen as a normal emotional response at one end, and it can be seen at different levels up to pathological jealousy where jealosy level is high but the person has a low insight. Cognitive jealousy includes irrational ideas and doubts about partner infidelity, behavioral jealousy includes superior effort to seek clues about infidelity; emotional jealousy includes intense anger, fear, sadness and guilt (Stravogiannis, 2018).

Jealousy can be seen as an adaptive and useful emotion because it can help to maintain relationships, but it may also lead to problematic behaviors such as aggression or rumination that contribute to psychopathology (Lennarz et al., 2017). Jealousy is associated whith low self-esteem, 
insecurity, skepticism, the psychological features which is associated with chronic depression, romantic relationship and marriage problems, aggression, suicide, homicide and amount of other negative consequences (Pines and Aronson, 1983).

Psychological resilience is defined as an individual's ability to positively adjust and adapt to adversity, difficulty, misfortune, or potentially traumatic event to maintain mental health. Jealousy is a powerful emotion defined as a negative feeling that arises when an individual perceives a threat from someone else to a valued relationship. Jealousy is often regarded as an invariable and unseemly trait of personality. However, understanding that experiencing this emotion in an intense and dysfunctional way is a side problem area related to low psychological resilience rather than being an invariable personality trait will make it possible to solve or alleviate the problem. The aim of this study is to clarifying the relationship between psychological resilience and jealousy in young adulthood.

\subsection{Limitations}

The fact that our sample consisted of young adults prevented us from obtaining information about the relationship between psychological resilience and jealousy of individuals in other age groups. In addition, the lower number of male participants compared to women is considered to be another limitation.

\section{Method}

The research of the study, which was conducted online in 2021, consists of 188 female (75.2\%), 62 are male (24.8\%), in total 250 volunteers who's age are between 18-45 and lives in Istanbul.

\subsection{Scales Used}


In the study, the Sociodemographic Data Form developed by the researcher for the analysis of the data, the Multidimensional Jealousy Scale to measure the jealousy levels of the individuals and the Psychological Resilience Scale for Adults were used to measure the psychological resilience of the individuals.

\subsubsection{Sociodemographic data form}

The sociodemographic data form includes gender, age, education level, economic level, marital status etc.

\subsubsection{Multidimensional jealousy scale.}

The multidimensional jealousy scale, developed by Pfeiffer and Wong (1987), consists of cognitive, emotional, and behavioral sub-dimensions. The multidimensional jealousy scale, a selfassessment scale, consists of 23 items. It was designated that reliability in development is between .80 and .90. In the pilot study conducted in the Turkish sample: for cognitive jealousy it is .91; for behavioral jealousy it is .86 and for emotional jealousy it is 86 (Karakurt, 2001).

\subsubsection{Psychological resilience scale.}

Psychological Resilience Scale for Adults was developed by Friborg et al. (2005) and adapted to Turkish by Basım and Çetin (2011). The Cronbach Alpha values of the sub-dimensions calculated for the reliability of the scale are between 0.66 and 0.81 ; In addition, the test-retest reliability ranges between 0.68 and 0.81 (Basım \& Çetin, 2011). The dimensions in the scale are named as 'self-perception', 'future perception', 'structural style', 'social competence', 'family adaptation' and 'social resources'. Cronbach Alpha values calculated for the reliability of the scale; It was calculated as 0.76 for 'Self Perception', 0.75 for 'Future Perception', 0.84 for 'Social Competence', 
0.89 for 'Family Harmony', 0.80 for 'Social Resources' and 0.76 for 'Structural Style'. Thus, the validity and reliability of the scale in the context of the selected sample were provided.

\subsection{Data Analysis and Interpretation}

The data obtained in the study were analyzed using the Statistical Program for Social Sciences (SPSS 25.0).

In order to control the normal distribution, skewness and kurtosis values were examined and it was decided that the scales and their sub-dimensions were between $-2+2$ values (George \& Mallery, 2010). The table on skewness and kurtosis values is given below.

Table 1. The Skewness and Kurtosis Values of the Adult Resilience Scale and the Multidimensional Jealousy Scale

\section{Skewness Kurtosis}

Multidimensional Jealousy Scale

Emotional

Behavioral

Cognitive

Psychological Resilience Scale

Self- Perception

Future Perception

Stuctrual Style

Social Competence
0.709

$-0.125$

$-1.172$

0.913

0.719

$-0.358$

0.906

$-0.296$

$-0.312$

$-0.730$

$-0.480$

$-0.430$

$-0.319$

$-0.737$

$-0.019$

$-0.846$

$-0.083$

$-0.394$ 
Family Harmony

Social Recources
$-0.540$

$-0.344$
$-0.536$

$-0.777$

When we provide the normal distribution, we prefer parametric analysis. In this study, the Independent Samples T-test was used to compare two independent groups and test the significance of the difference. The relationship between the scales was examined with Pearson Correlation analysis. Since the duration of education and income level are categorical variables and the scores obtained from the scales are constantly variable, the correlation between these variables was calculated using Spearman Brown Rank Differences Correlation. Finally, Multiple Linear Regression analysis was preferred to analyze the independent variables to predict the dependent variable.

\section{Findings}

$75.2 \%$ of the participants are women, $24.8 \%$ are men, $3.2 \%$ are primary school graduates, $18.0 \%$ are high school graduates, $12.4 \%$ are associate degree, $54 \% .3$ undergraduate, $11.6 \%$ graduate, $0.8 \%$ doctorate, $14.4 \%$ had poor total income, $62.8 \%$ had medium income, $22.8 \%$ had good total income, $\% 9.6 \%$ have no siblings, $30 \%$ have 1 sibling, $24.8 \%$ have 2 siblings, $19.6 \%$ have 3 siblings, $7.6 \%$ have 4 siblings, $8.4 \%$ has more than 4 siblings, $34.4 \%$ are married and $65.6 \%$ are single.

Multidimensional Jealousy Scale average $(\overline{\mathrm{X}}=85.40, \mathrm{SS}=28.44)$, Emotional average $(\overline{\mathrm{X}}=38.69$, $\mathrm{SS}=9.18)$, Behavioral average $(\overline{\mathrm{X}}=24.74, \mathrm{SS}=12.96)$, Cognitive average $(\overline{\mathrm{X}}=21.96, \mathrm{SD}=$ 14.33), Adult Resilience Scale average $(\overline{\mathrm{X}}=111.34$, SD $=27.00)$, Self-Perception average $(\overline{\mathrm{X}}=$ 21.26, SS $=6.00)$, Future Perception average $(\bar{X}=13.92, S S=4.39)$, Structural Style average $(\bar{X}$ $=13.13, \mathrm{SD}=4.22)$, Social Competence average $(\overline{\mathrm{X}}=19.41, \mathrm{SD}=5.20)$, Family Adjustment average $(\bar{X}=19.31, S S=5.07)$, Social Resources average $(\bar{X}=24.30, S D=7.13)$.

When we examine the findings, it is seen that the mean age of the sample is 29 (sd=6). 
Table 2. Results of Examining the Relationship Between Sociodemographic Variables and the Adult Resilience Scale

\begin{tabular}{|c|c|c|c|}
\hline & & $\mathbf{n}$ & $\%$ \\
\hline \multirow[t]{3}{*}{ Sex } & Woman & 188 & 75.2 \\
\hline & Man & 62 & 24.8 \\
\hline & Total & 250 & 100.0 \\
\hline \multirow[t]{7}{*}{ Education Status } & Primary & 8 & 3.2 \\
\hline & High school & 45 & 18.0 \\
\hline & Associate degree & 31 & 12.4 \\
\hline & Bacheloar degree & 135 & 54.0 \\
\hline & Master & 29 & 11.6 \\
\hline & Phd & 2 & 0.8 \\
\hline & Total & 250 & 100.0 \\
\hline \multirow[t]{4}{*}{ Level of in Come } & Not Good & 36 & 14.4 \\
\hline & Good & 157 & 62.8 \\
\hline & Very Good & 57 & 22.8 \\
\hline & Total & 250 & 100.0 \\
\hline \multirow[t]{4}{*}{ Number of Sibling } & 0 & 24 & 9.6 \\
\hline & 1 & 75 & 30.0 \\
\hline & 2 & 62 & 24.8 \\
\hline & 3 & 49 & 19.6 \\
\hline
\end{tabular}




\begin{tabular}{llll}
4 & 19 & 7.6 \\
& 4 upper & 21 & 8.4 \\
Total & 250 & 100.0 \\
\hline Marital Status & Maried & 86 & 34.4 \\
& Single & 164 & 65.6 \\
& Total & 250 & 100.0 \\
\hline
\end{tabular}

** $p<0.01, * p<0.05$ Test used: Pearson and Spearman Correlation Test

Table 3. Results of Examining the Relationship Between the Adult Resilience Scale and the Multidimensional Jealousy Scale

\section{Jealousy Total Emotional Behaviroal Cognitive}

\begin{tabular}{lllll}
\hline Psychological Resilience Scale & $-.359^{* *}$ & $-.236^{* *}$ & $-.262^{* *}$ & $-.325^{* *}$ \\
Self- Perception & $-.353^{* *}$ & $-.250^{* *}$ & $-.285^{* *}$ & $-.283^{* *}$ \\
Future Perception & $-.284^{* *}$ & $-.140^{*}$ & $-.224^{* *}$ & $-.271^{* *}$ \\
Stuctrual Style & $-.277^{* *}$ & $-.137^{*}$ & $-.203^{* *}$ & $-.280^{* *}$ \\
Social Competence & $-.316^{* *}$ & $-.226^{* *}$ & $-.213^{* *}$ & $-.289^{* *}$ \\
Family Harmony & $-.273^{* *}$ & $-.184^{* *}$ & $-.182^{* *}$ & $-.259^{* *}$ \\
Social Recources & $-.301^{* *}$ & $-.220^{* *}$ & $-.210^{* *}$ & $-.266^{* *}$ \\
\hline
\end{tabular}

** $p<0.01, * p<0.05$ Test used: Pearson Correlation Test

Table 4. Findings of Resilience Predicting Jealousy 


\begin{tabular}{lccccc}
\hline & $\boldsymbol{B}$ & $\boldsymbol{S H}$ & $\boldsymbol{\beta}$ & $\boldsymbol{t}$ & $\boldsymbol{p}$ \\
\hline (Costant) & 130.28 & 7.15 & & 18.23 & $0.000^{*}$ \\
Self - Perception & -1.23 & 0.33 & -0.26 & -3.72 & $0.000^{*}$ \\
Social Competence & -0.97 & 0.38 & -0.18 & -2.55 & $0.011^{*}$ \\
\hline $\boldsymbol{R}=\mathbf{3 8} \quad \boldsymbol{R}^{2}=\mathbf{1 4}$ & & & & \\
$\boldsymbol{F}=\mathbf{2 1 . 3 3} \quad \boldsymbol{p}=\mathbf{0 . 0 0 0}$ & & & & \\
$* p<0.05$ & Test used: Multiple Linear Regression Analysis
\end{tabular}

Table 5. Findings Regarding the Comparison of Multidimensional Jealousy and Adult Resilience Scale Scores According to the Marital Status Variable

\begin{tabular}{|c|c|c|c|c|c|c|c|}
\hline & & & $\mathrm{n}$ & Ss. & t. & Sd & p. \\
\hline & & $n$ & $\bar{X}$ & Ss. & $t$ & $S d$. & $p$ \\
\hline \multirow[t]{2}{*}{ Çok Boyutlu Kıskançlık Ölçeği } & Maried & 86 & 79.80 & 26.26 & -2.27 & 248 & $0.024 *$ \\
\hline & Single & 164 & 88.33 & 29.18 & & & \\
\hline \multirow[t]{2}{*}{ Emotional } & Maried & 86 & 37.19 & 10.01 & -1.89 & 248 & 0.060 \\
\hline & Single & 164 & 39.48 & 8.64 & & & \\
\hline \multirow[t]{2}{*}{ Behavioral } & Maried & 86 & 24.21 & 13.65 & -0.47 & 248 & 0.638 \\
\hline & Single & 164 & 25.02 & 12.62 & & & \\
\hline \multirow[t]{2}{*}{ Cognitive } & Maried & 86 & 18.41 & 13.15 & -2.88 & 248 & $0.004^{*}$ \\
\hline & Single & 164 & 23.82 & 14.61 & & & \\
\hline \multirow[t]{2}{*}{ Adult Resilience Scale } & Maried & 86 & 116.94 & 25.93 & 2.40 & 248 & $0.017 *$ \\
\hline & Single & 164 & 108.40 & 27.17 & & & \\
\hline \multirow[t]{2}{*}{ Self - Perception } & Maried & 86 & 22.37 & 5.43 & 2.13 & 248 & $0.034^{*}$ \\
\hline & Single & 164 & 20.68 & 6.21 & & & \\
\hline \multirow[t]{2}{*}{ Future Perception } & Maried & 86 & 14.49 & 4.35 & 1.49 & 248 & 0.138 \\
\hline & Single & 164 & 13.62 & 4.39 & & & \\
\hline \multirow[t]{2}{*}{ Structual Style } & Maried & 86 & 13.70 & 4.22 & 1.55 & 248 & 0.123 \\
\hline & Single & 164 & 12.83 & 4.21 & & & \\
\hline \multirow[t]{2}{*}{ Social Competence } & Maried & 86 & 20.72 & 5.14 & 2.93 & 248 & $0.004 *$ \\
\hline & Single & 164 & 18.72 & 5.12 & & & \\
\hline
\end{tabular}




\begin{tabular}{llllllll} 
Family Harmony & Maried & 86 & 20.20 & 4.76 & 2.01 & 248 & $0.045^{*}$ \\
& Single & 164 & 18.85 & 5.18 & & & \\
\hline Social Recources & Maried & 86 & 25.47 & 7.23 & 1.87 & 248 & 0.062 \\
& Single & 164 & 23.70 & 7.03 & & & \\
\hline
\end{tabular}

* $\mathrm{p}<0.05$ Test Used: Independent Samples T-Test

\section{Discussion}

Psychological resilience is defined as a person's adaptation process, ability to recover or the ability to overcome change / disasters successfully against major stressors such as a trauma, a threat, a tragedy or family and relational troubles, serious health problems, workplace and financial problems ( Kocjan, 2021). Jealousy, on the other hand, is an emotion that includes anxiety about maintaining the relationship and fears about the ending of the relationship. This complex emotion, which contains the feelings of anxiety and fear in his heart, is felt as a result of a damage or loss that may occur due to the physical or fantasy existence of a third person who is seen as a rival in bilateral relations. Feelings of anxiety and fear, which are among the most basic contents of jealousy, are clear signs that the individual does not adapt to the situation they face. In this respect, the main hypothesis of our study is that there is an inverse relationship between resilience and jealousy. The findings of our study showed that there is an inverse relationship between resilience and jealousy.

The relationship between resilience and jealousy was explained by the sub-dimension of psychological resilience self-perception that explained at the highest level (R2 14\%). There was an opposite relationship between them. Self-perception adoption means self-acceptance, a factor that increases psychological resilience (Huang et al., 2020). Having a positive self-acceptance creates self-esteem (Öner, 2019). Jealousy is a very weary and compelling feeling. The high level of jealousy, which is a feeling of real or imaginary loss, indicates low self-esteem and lack of selfconfidence (Greenberg \& Pyszczynski, 1985). 
The results of plenty of studies indicated that psychological resilience had positive relationship with self-esteem which has a relationship with jealosuy (Kapikiran \& Acun-Kapikiran, 2016; Shi et al., 2016; Song, Fu, \& Wang, 2019; Zhao et al., 2020). According to Sanford and Donovan (1999), the level of self-esteem; It affects the individual's thoughts, words and everything he does, his world, his place in the world, his view of the world, how other people see him, his vital choices, his ability to give and receive love, and his ability to act to change what needs to be changed. As stated by Sanford and Donovan regarding self-esteem, it has been observed that the concepts of psychological resilience and self-esteem are interrelated, and increased self-esteem leads to an increase in psychological resilience (Sarıkaya, 2015; Pınar et al., 2018; Öner, 2019). In case of jealousy, with the decrease in self-esteem, the level of reaction to jealousy increases (Demirtaş \& Dönmez, 2006).

One of the internal protective factors of resilience is self-acceptance, which refers to the cognition and judgment of the actual self and the acceptance of the actual self in emotion and attitude). Selfacceptance is a positive attitude toward every aspect of individual's past, present and future, which is an important sign of mental health (Xu et al., 2017). However, when the individual is not selfacceptance, it is easy to produce a sense of inferiority

Another finding of our study is that psychological resilience is higher in married individuals and jealousy is higher in single individuals. Bozgeyikli and Şat (2014) and Fingerless (2020) concluded that marital status significantly differentiates psychological resilience scores, in line with our findings. The type of relationship is influential on the methods adopted in dealing with jealousy; married people use constructive methods more often than unmarried ones, and unmarried ones use destructive methods more often than married ones (Demirtaş \& Dönmez, 2006).

In the relevant literature, it is possible to come across studies stating that the support provided in the marital relationship makes individuals mentally stronger (Stack \& Eshleman, 1998) and functions as a protective factor supporting their psychological resilience in stress situations (Guinn, Vincent, \& Dugas, 2009). In addition, answering the need for loneliness, meeting emotional, social and economic needs in a relationship and sharing life responsibilities, which are among the outputs of marriage, are a protective factor for psychological resilience (Bektaş \& Özben, 2016).

In addition to increasing psychological resilience (Oliveira et al., 2017), the level of psychological resilience also determines whether the individual can have a long-term and responsible relationship 
such as marriage. For example, it is known that the crime rate of unmarried individuals is higher than the single ones, which indicates low psychological resilience (Cantürk et al., 2021). Regardless of the type (neglect, physical, sexual, and psychological abuse), all childhood traumas negatively affect the psychological resilience of individuals (Aydın, 2018; Doğruer, 2019). The fact that childhood traumas are higher in unmarried or divorced individuals (Cantürk et al., 2021) is another example that points to the relationship between psychological resilience and marriage. It has been reported that there is a negative relationship between resilience and anger (Şahin, 2019). Similarly, Turan (2021) revealed in his study that people who were subjected to anger management psychoeducation increased their psychological resilience. Anger, often appears as jealousy in close interpersonal relationships (Stockdale et al. 2015). Intense anger is the basic way to maintain contact with the needed object, to control it and to maintain the sense of self depending on the relationship with the object. It is thought that the emotion expressed in anger is considered to be jealousy, especially in close relationships, where the fear of loss increases in parallel with the growth and importance of the other's place in our lives.

Another finding of our research is that the psychological resilience of the participants increases in parallel with the age of the participants. Some researchers have noted that older students are more likely to use positive coping strategies than younger students (Monteno, 2014).

One of the findings of our study is that there is a positive relationship between psychological resilience and income level. A study reveals that people who express their monthly income as sufficient have higher psychological resilience than those who express as insufficient (Pinar et al., 2018) and another reveals that individuals with higher monthly family income have higher resilience scores (Huang, 2020). Good family economic conditions are protective factors of psychological resilience, which could provide individuals with more physical and emotional support, making offenders more optimistic and confident, thus increasing the level of their resilience (Oliveira et al., 2017). Studies shows that Low socio-economic level, economic difficulties and poverty are among the factors affecting negatively psychological resilience (Arslan, 2015; Güngörmüş et al., 2015; Beştaş ve Özben, 2016; Pınar et al., 2018).

One of the findings of our study is that psychological resilience levels are higher in women. Moreover, this is also true for women of different age groups. The results of the study conducted by Yildırım et al. (2015) with adolescent students and the results of the study conducted by Tümlü 
and Recepoğlu (2013) with academicians reveal that women have higher levels of psychological resilience similar to us. Although this situation can be explained by the fact that women are given responsibility from an early age in Turkish culture and they have to cope with more problems due to the higher social expectations than women, similar results are encountered in foreign literature. According to O'dowd et al. (2018), 57\% of psychological resilience is coping mechanisms. Some previous studies showing that males' positive coping style scores were lower than those of females. Females using more help-seeking behaviours and emotion-focused coping than males so they are getting more social support (Felsten, 1998; Liu et al., 2017).

Another finding of our study is that women's emotional jealousy levels are higher. This result can be explained by the fact that although men's autonomy is supported from an early age in our society, women's autonomy is restricted regardless of their age, and their relationship needs are evident in women structurally. This is consistent with Mesutoğlu's (2012) study that men's autonomous-discrete self-construal scores were significantly higher than women's dependentrelational self-construal scores, and Dost (2006 )'s study that women's autonomous-relational selfconstruct was significantly different from men's. It is expected that altruistic behaviors are more common in women with self-construct characterized by relationality. According to Budak (2009), the main thing in altruistic behavior is to act for the benefit of someone else and to think of someone else's benefit rather than your own. It has been determined that altruism is a personal protective factor affecting psychological resilience (Fingerless, 2020). These findings in the literature are consistent with the higher psychological resilience and emotional jealousy of women, which is one of the results of our study. Women can be both more altruistic and jealous due to the importance they attach to relationships.

The neuroticism dimension of the five-factor personality inventory, which has been widely used for many years in personality evaluations, is characterized by emotional instability. Individuals with high levels of neuroticism are considered to be anxious, insecure, angry, and resentful individuals (Doğan, 2012). The feeling of jealousy, in which concerns about the loss of the relationship with the other, insecurity and anger after the loss are at the forefront, is a feeling that is quite possible to be found in the spiritual world of the neurotic personality. Consistent with our findig which says there is a signifcant relationship between psychological resilience and jealousy, Oshio et al.,(2018) and Kojgan et al. (2021) showed a strong negative correlation with neuroticism and psychological resilience. 
Individuals high in neuroticism are more attentive to negative stimuliand experience elevated negative emotionality in adverse situations (Tackett \& Lahey, 2017), which decreases capacity to successfully adjust to adverse situation. The associations obtained between the Big Fiveand resilience indicate that individuals who had low lev-els of negative emotions (low neuroticism), showed higher levels of resilienceduring the COVID-19 lockdown (Kocjan, 2021)

\section{Conclusion}

As a result of our study, it was seen that resilience occupies a very important place in the life of the individual and has important effects on many points from his self-perception to his emotions and his relationships with others. Psychological resilience is also known as a personal trait that can be learned and improved upon (Hunter and Warren, 2014). In this direction, it is of great importance to increase psychological resilience in order to increase our contact with positive emotions, to establish more satisfying relationships and to adapt to various living conditions. The positive effect of self-confidence-enhancing psychotherapeutic interventions, enhancing critical thinking skills and problem-solving skills, and strengthening the social support system can be utilized in increasing psychological resilience (Pınar et al., 2018).

Conflict of Interest: The authors have no conflict of interest to declare.

Financial Disclosure: The authors declared that this study has received no financial support.

\section{References}

ARSLAN, G. (2015). Resilience in adolescents: the role of individual protective factors. Turk. Psychol. Couns. Guid. J. 5 (44), 149-158. 
AYDIN, E. (2018). Çocukluk çă̆l travmatik yaşantılarının psikolojik sağlamlık ve depresyon belirtileri üzerine etkisi. Yayınlanmış Yüksek Lisans Tezi. Fatih Sultan Mehmet Vakıf Üniversitesi, İstanbul.

BASIM, H.N., CETIN, F. (2011). The reliability and validity of the Resilience Scale for Adults-Turkish Version. Turk Psikiyatri Derg, 22(2), 104-113.

BEKTAŞ, M., ÖZBEN. Ş. (2016). married bireylerin psikolojik dayanıklılık düzeylerinin bazı sosyo-demografik değişkenler açısından incelenmesi. Celal Bayar University Journal of Social Sciences/Celal Bayar Üniversitesi Sosyal Bilimler Dergisi, 14(1), 216-240.

CANTÜRK, M., FARAJI, H. \& TEZCAN, A.E. (2021). The relationship between childhood trauma and crime in male prisoners, Alpha Psychiatry, 22, 56-60.

DE OLIVEIRA, A.C.P., MACHADO, A.P.G., ARANHA, R.N. (2017). Identification of factors associated with resilience in medical students through a cross-sectional census. BMJ open, $7(11), 1-8$.

DEMİRTAŞ, H.A., DÖNMEZ, A. (2006). Yakın ilişkilerde kıskançlık: Bireysel, ilişkisel ve durumsal değişkenler. Türk Psikiyatri Dergisi, 17(3), 181-191.

DOĞRUER, N. (2019). Çocukluk çă̆l travma yaşantılarına sahip yetişkinlerde psikolojik dayanıklılık ve affetme. Yayınlanmamış yüksek lisans tezi, Yakın Doğu Üniversitesi, Lefkoşa.

DOST, A. (2006). The relationship between self construals and language for emotions in personal narratives of turkish males and females (Yayınlanmamış yüksek lisans tezi), Koç Üniversitesi Sosyal Bilimler Enstitüsü, İstanbul.

FARAJI, H., GÜLER, K. (Şubat, 2020). Borderline Personality Disorder Features and Jealiousy Traits In University Students, I. Uluslararası Sosyal Bilimlerde Davranış Temelli Araştırmalar Sempozyumu, İstanbul.

FELSTEN, G. (1998). Gender and coping: use of distinct strategies and associations with stress and depression. Anxiety Stress Coping. 11: 289-309.

FRİBORG, O., BARLAUG, D., MARTINUSSEN, M., ROSENVINGE, J.H., HJEMDAL, O., (2005), Resilience in Relation to Personality and Intelligence, International Journal of Methods in Psychiatric Research, 14:1, s. 29-42. 
GEORGE, D. \& MALLERY, M. (2010). SPSS for Windows Step by Step: A Simple Guide and Reference, 17.0 update (10a ed.) Boston: Pearson.

GÜNGÖRMÜŞ, K., OKANLI, A., KOCABEYOĞLU, T., (2015). Factors influencing resilience in nursing students. J. Psy. Nurs. 6 (1), 9-14.

HAASE, J.E., (2004), The Adolescent Resilience Model as a Guide to Interventions, Journal of Pediatric Oncology Nursing, 21, 289-299.

HERRMAN, H., STEWART, D.E., DİAZ-GRANADOS, N., BERGER, E.L., JACKSON, B., YUEN. T. (2011). What is resilience?. The Canadian Journal of Psychiatry, 56(5), 258-265.

HOWELL, K.H., MILLER-GRAFF, L.E., SCHAEFER, L.M., SCRAFFORD, K.E. (2020). Relational resilience as a potential mediator between adverse childhood experiences and prenatal depression. Journal of health psychology, 25(4), 545-557.

HUANG, Y., WU, R., WU, J., YANG, Q., ZHENG, S., WU, K. (2020). Psychological resilience, self-acceptance, perceived social support and their associations with mental health of incarcerated offenders in China. Asian Journal of Psychiatry, 52, 1-7.

KAPIKIIRAN, S., ACUN-KAPIKİRAN, N. (2016). Optimism and psychological resilience in relation to depressive symptoms in University students: Examing the mediating role of self-esteem. Educaton Science: Theory \& Practice, 16(6), 2087-2110.

KARAKURT, G. (2001). The impact of adult attachment styles on romantic jealousy. Master thesis, Middle East Technical University, Ankara.

KOCJAN, G.Z., KAVČİČ, T., AVSEC, A. (2021). Resilience matters: Explaining the association between personality and psychological functioning during the COVID-19 pandemic, International Journal of Clinical and Health Psychology, 21(1), 1-9.

LENNARZ, H.K., LİCHTWARCK-ASCHOFF, A., FINNENAUER, C., GRANIC, I. (2017). Jealousy in adolescents' daily lives: How does it relate to interpersonal context and well-being?. Journal of Adolescence, 54, 18-31.

LIUU, F., ZHOU, N., CAO, H., FANG, X., DENG, L., CHEN, W., ET AL. (2017). Chinese college freshmen's mental health problems and their subsequent help-seeking behaviors: a cohort design (2005-2011) PLoS One. 12(10), 1-17. 
MESUTOĞLU, C. (2012). Lise öğrencilerinde cinsiyet bağlaminda benlik kurgusu, aile işlevselliği ve kardeş sayısı arasındaki ilişki (Yayımlanmamış yüksek lisans tezi), Ortadoğu Teknik Üniversitesi Sosyal Bilimler Enstitüsü, Ankar.

MONTEIRO, N.M., BALOGUN, S.K., ORATILE, K.N. (2014). Managing stress: the influence of gender, age and emotion regulation on coping among university students in Botswana. Int J Adolesc Youth. 19,153-173.

O’DOWD, E., O'CONNOR, P., LYDON, S., MONGAN, O., CONNOLLY, F., DİSKIN, C., BYRNE, D. (2018). Stress, coping, and psychological resilience among physicians. BMC health services research, 18(1), 1-11.

PARMAKSIZ, İ. (2020). İyimserlik, özgecilik ve medeni durumun psikolojik dayanıklılık üzerindeki etkileri. Pamukkale Üniversitesi Eğitim Fakültesi Dergisi, 48, 285302.

PINES, A., ARONSON, E. (1983). Antecedents, correlates, and consequences of sexual jealousy. Journal of Personality, 51, 108-136. http://dx.doi.org/10.1111/j.14676494.1983.tb00857.x.

RISTEVSKA-DİMITROVSKA, G., FILOV, I., RAJCHANOVSKA, D., STEFANOVSKİ, P., DEJANOVA, B. (2015). Resilience and quality of life in breast cancer patients. Open access Macedonian journal of medical sciences, 3(4), 727-731.

SARIKAYA, A. (2015). 14-18 yaş arası ergenlerin benlik saygısı ve psikolojik dayanıklllk düzeyleri arasındaki ilişki (Master's thesis, İstanbul Bilim Üniversitesi, Sosyal Bilimler Enstitüsü.).

SHİ, J., CHEN, Z., YİN, F., ZHAO, J., ZHAO, X., YAO, Y. (2016). Resilience as moderator of the relationship between left-behind experience and mental health of Chinese adolescents. The International Journal of Social Psychiatry, 62(4), 386-393.

SONG, C., FU, Z., WANG, J. (2019). Social support and academic stress in the development of psychological adjustment in Chinese migrant children: Examination of compensatory model of psychological resilience. Child Indicators Research, 12(4), 12751286. 
STRAVOGİANNIS, A.L.D.C., KİM, H.S., SOPHİA, E.C., SANCHES, C., ZİLBERMAN, M.L., TAVARES, H. (2018). Pathological jealousy and pathological love: Apples to apples or apples to oranges?. Psychiatry research, 259, 562-570.

TAKU, K. (2014). Relationships among perceived psychological growth, resilience and burnout in physicians. Personality and individual differences, 59, 120-123.

TURAN, N. (2021). An investigation of the effects of an anger management psychoeducation programme on psychological resilience and affect of intensive care nurses. Intensive and Critical Care Nursing, 62, 1-9.

ZHAO, X., FU, F., ZHOU, L. (2020). The mediating mechanism between psychological resilience and mental health among left-behind children in China. Children and Youth Services Review, 110, 1-7. 